\title{
A novel cytogenetic abnormality r(7)(::p11.2->q36.3::) in a Philadelphia-positive chronic myeloid leukemia case
}

\author{
Walid Al Achkar ${ }^{1^{*}}$, Abdulsamad Wafa $^{1}$, Abdulmunim Aljapawe $^{2}$, \\ Moneeb Abdullah Kassem Othman ${ }^{3}$, Thomas Liehr ${ }^{3}$ \\ ${ }^{1}$ Human Genetics Division, Molecular Biology and Biotechnology Department, Atomic Energy Commission, Damascus, Syria; \\ *Corresponding Author: ascientific@aec.org.sy \\ ${ }^{2}$ Mammalians Biology Division, Molecular Biology and Biotechnology Department, Atomic Energy Commission, Damascus, Syria \\ ${ }^{3}$ Jena University Hospital, Institute of Human Genetics, Jena, Germany
}

Received 24 September 2013; revised 17 October 2013; accepted 18 November 2013

Copyright (C) 2013 Walid Al Achkar et al. This is an open access article distributed under the Creative Commons Attribution License, which permits unrestricted use, distribution, and reproduction in any medium, provided the original work is properly cited. In accordance of the Creative Commons Attribution License all Copyrights (C) 2013 are reserved for SCIRP and the owner of the intellectual property Walid Al Achkar et al. All Copyright (C) 2013 are guarded by law and by SCIRP as a guardian.

\section{ABSTRACT}

The so-called Philadelphia (Ph) chromosome is present in more than $90 \%$ of chronic myeloid leukemia (CML) cases. It results in juxtaposition of the $5^{\prime}$ part of the $B C R$ gene on chromosome 22 and the 3' part of the ABL1 gene on chromosome 9. An additional acquired monosomy 7 or deletion of $7 q$ is associated with poor prognosis in a variety of myeloid disorders. Here we report a novel $\mathrm{Ph}$ chromosome positive CML case with a ring chromosome 7 [r(7)]. Immunophenotyping was compatible with CML, although $4.5 \%$ of total leucocytes appeared like acute myelogeneous leukemia (AML) subtype M2. The $r(7)$ was characterized in detail by array-proven multicolor banding (aMCB), the latter being of enormous significance to characterize breakpoint regions in detail. Underlying mechanisms and prognostic are discussed, as ring chromosomes are rare cytogenetic abnormalities in hematopoietic malignancies.

Keywords: Chronic Myeloid Leukemia (CML); Ring Chromosome 7; Del(7p); Fluorescence in Situ Hybridization (FISH); Reverse Transcription Polymerase Chain Reaction (RT-PCR); Array-Proven Multicolor Banding (aMCB)

\section{INTRODUCTION}

The so-called Philadelphia $(\mathrm{Ph})$ chromosome is typical for by far over $95 \%$ of patients suffering form chronic myeloid leukemia (CML), a clonal malignant disorder of a pluripotent hematopoietic stem cell. A reciprocal translocation $\mathrm{t}(9 ; 22)(\mathrm{q} 34 ; \mathrm{q} 11)$ leads to the formation of the Philadelphia $(\mathrm{Ph})$ chromosome and a derivative of chromosome 9. The 3 ' portion of the $A B L 1$ oncogene is translocated from $9 \mathrm{q} 34$ to the 5 portion of the BCR gene on 22q11.2. This leads to the formation of a chimeric $\mathrm{BCR} / \mathrm{ABL}$ gene on the derivative chromosome 22 [1]. It is known since years that the expression of the chimeric $\mathrm{BCR} / \mathrm{ABL}$ protein has an increased tyrosine kinase activity and plays an essential role in the pathogenesis of CML [2].

Ring chromosomes are rare cytogenetic abnormalities that occur when the two ends of a chromosome fuse together and form a ring shape. Breaks in the chromosome arms and fusion of the proximal broken ends can lead to ring formation with loss of distal chromosomal material. Alternatively, rings can be formed by telomere dysfunction [3].

Complete or partial loss of chromosome 7, predominantly monosomy 7 or deletion of $7 \mathrm{q}$, is associated with a variety of myeloid disorders, including de novo preleukemic myelodysplastic syndrome (MDS) and acute myelogenous leukemia (AML) in children and adults, as well as therapy-related ones in the latter [4,5]. Also it has been reported in adult ALL, in which they frequently occur as secondary aberrations associated with a $\mathrm{Ph}$ chromosome and it is an adverse factor in both childhood and adult $\mathrm{Ph}+\mathrm{ALL}$ [6]. Additionally, deletions of $7 \mathrm{p}$ confer an inferior outcome in children with ALL, regardless of the presence of other poor prognostic features, 
whereas deletions of $7 \mathrm{q}$ are not associated with a worse outcome [6].

Here we reported a novel case of a $\mathrm{Ph}$ chromosome positive CML with $\mathrm{r}(7)$ and immunophenotyping consistent with CML, although $4.5 \%$ of total leucocytes showed AML M2 subtype.

\section{MATERIALS AND METHODS}

\subsection{Case Report}

A 55-year-old male was diagnosed as suffering from CML in chronic phase (CP). In June 2010 the white blood cell count (WBC) was $93 \times 10^{9} / 1$ with $49.3 \%$ neutrophils, $19.6 \%$ lymphocytes, $14.1 \%$ monocytes, $3.4 \%$ eosinophils, and $13.6 \%$ basophils. The platelets count was $181 \times 10^{9} / 1$ and the hemoglobin level was $10.6 \mathrm{~g} / \mathrm{dl}$. A previous physical examination revealed splenomegaly. Serum lactate dehydrogenase (LDH) was 2057 U/1 (normal up to $480 \mathrm{U} / \mathrm{l}$ ), serum alanine aminotransferase (ALT) was $46 \mathrm{U} / 1$ (normal up to $41 \mathrm{U} \backslash \mathrm{l}$ ) and serum aspartate aminotransferase (AST) was $42 \mathrm{U} / 1$ (normal up to $40 \mathrm{U} / 1$ ). Afterwards he was lost during follow-up.

\subsection{Chromosome Analysis}

Chromosome analysis using GTG-banding was performed according to standard procedures [7] before chemotherapeutic treatment. A total of 20 metaphase cells derived from unstimulated bone marrow culture were analyzed. Karyotypes were described according to the International System for Human Cytogenetic Nomenclature [8].

\subsection{Molecular Cytogenetics}

Fluorescence in situ hybridization (FISH) using LSI $\mathrm{BCR} / \mathrm{ABL}$ dual color dual fusion translocation probe (Abbott Molecular/Vysis, USA) was applied according to manufacturer's instructions [9]. FISH using a chromosome-7-specific aMCB probe set based on microdissection derived region-specific libraries was done as previously reported [10]. A total of 20 metaphase spreads were analyzed, each using a fluorescence microscope (AxioImager.Z1 mot, Zeiss) equipped with appropriate filter sets to discriminate between a maximum of five fluorochromes plus the counterstain DAPI (4',6-diamino-2-phenylindole). Image capturing and processing were carried out using an ISIS imaging system (MetaSystems, Altlussheim, Germany).

\subsection{Reverse Transcriptase-Polymerase Chain Reaction (RT-PCR) for BCR/ABL Fusion Transcripts}

RT-PCR was carried out as previously described [11].

\subsection{Immunophenotyping}

Immunophenotyping of leukemic blasts was performed as previously described [12].

\section{RESULTS}

Prior to chemotherapy treatment banding cytogenetics revealed a karyotype $46, \mathrm{XY}, \mathrm{t}(9 ; 22)$ [7]/46, XY, idem, r(7) [11]/47, XY, idem + 8 [2] (Figure 1(a)). Dual-colorFISH using a probe specific for BCR and ABL revealed that a typical $\mathrm{Ph}$ chromosome with BCR/ABL-translocation was present (Figure 1(b)). RT-PCR analysis of the fusion transcript showed a band corresponding to the b2a2 transcript, most often found in CML (data not shown). Together with aMCB-result (Figure 1(c)) the final karyotype was determined as: 46, XY, $\mathrm{t}(9 ; 22)(\mathrm{q} 34 ; \mathrm{q} 11)[7] / 46, X Y, \mathrm{r}(7)(:: \mathrm{p} 11.2->\mathrm{q} 36.3::)$, $\mathrm{t}(9 ; 22)(\mathrm{q} 34 ; \mathrm{q} 11)[11] / 47, \mathrm{XY},+8, \mathrm{t}(9 ; 22)(\mathrm{q} 34 ; \mathrm{q} 11)[2] /$.

The specimen submitted has a high WBC count $>100,000$ cells $/ \mathrm{mm}^{3}$. Neutrophiles $(86 \%$ of all leucocytes), showed abnormal intensity staining patterns for CD16 (49.4\%), CD32 (62.7\%), CD10 (31\%), CD33 (49.4\%), CD15 (57.1\%), CD13 (43.3\%), CD11b (27.2\%), and CD11c (41.5\%). These cells expressed CD123 $(67.5 \%)$. Overall, this result was indicative for chronic

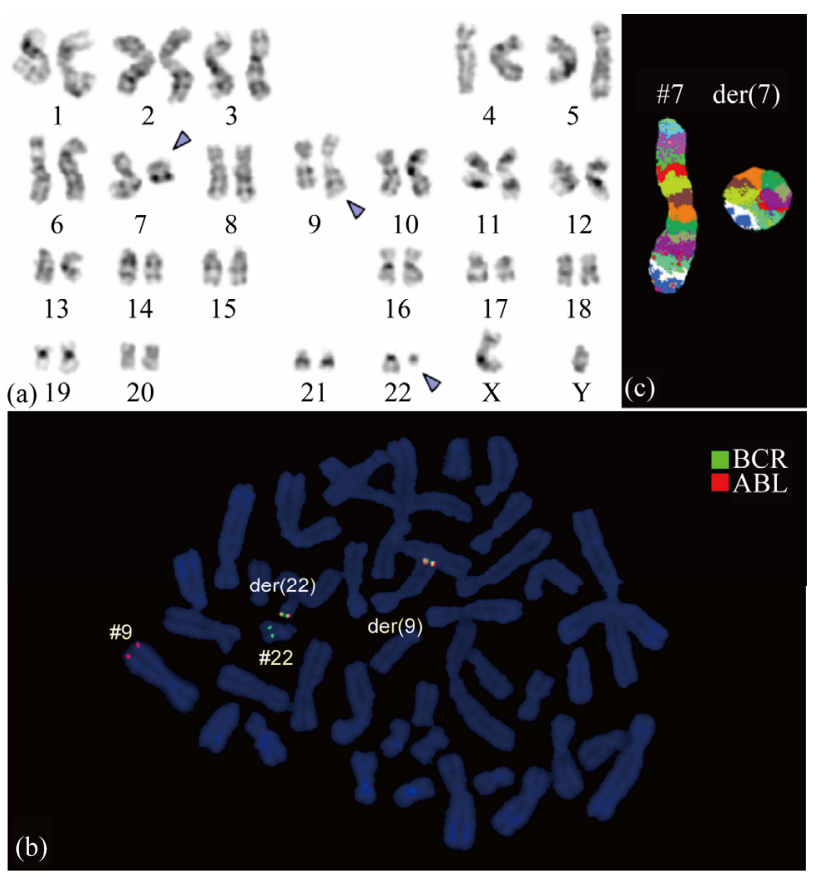

Figure 1. (a) GTG-banding revealed a $\mathrm{r}(7)(:: \mathrm{p} 11.2->\mathrm{q} 36.3::)$ besides derivative chromosomes 9 and 22. All derivative chromosomes are highlighted by arrow heads; (b) Metaphase FISH using probes for BCR (green) and $\mathrm{ABL}$ (red) confirmed $\mathrm{Ph}$ chromosome presence; (c) The application of aMCB 7 characterized the $\mathrm{r}(7)(:: \mathrm{p} 11.2->\mathrm{q} 36.3::)$ comprehensively. Abbreviations: $\#=$ chromosome; der $=$ derivative chromosome; $\mathrm{Ph}=$ Philadelphia-chromosome. 
myeloproliferative disorder, most likely a CML, subsequent to an MDS. However, there was as well another cell population, which represented $\sim 4.5 \%$ of all leucocytes, showing an AML-M2 phenotype. These cells have high forward scatter, low side scatter pattern and were $\mathrm{CD} 45+\operatorname{dim}(4.5 \%), \mathrm{CD}_{4} 4^{+}(4.9 \%), \mathrm{CD}_{3} 3^{+}(4.4 \%)$, $\mathrm{CD} 38^{+}(4.8 \%), \mathrm{CD}^{+} 2^{+}(4.9 \%), \mathrm{CD}^{2} 23^{+}(4.9 \%)$. These cells expressed CD13 (2.6\%), CD15 (2.5\%), CD11c (1.9\%), HLADr (2.8\%), CD117 (2.3\%) heterogeneously,

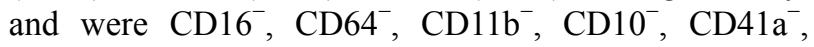
$\mathrm{CD} 235 \mathrm{a}^{-}, \mathrm{CD}^{-}, \mathrm{CD} 19^{-}$.

\section{DISCUSSION}

According to the literature, a $r(7)$ involved the short arm is a rare but recurrent cytogenetic abnormality observable in AML $\{\mathrm{r}(7)(\mathrm{p} 15 \mathrm{q} 35)$ and $\mathrm{r}(7)(\mathrm{p} 22 \mathrm{q} 31)\}$ [13], hepatosplenic T-cell lymphoma [r(7)(p?;q?) [14]] and acute megakaryoblastic leukemia [15]. To the best of our knowledge, the present case is the only one ever seen case of a Ph chromosome-positive CML-CP with de novo a $\mathrm{r}(7)(:: \mathrm{p} 11.2->\mathrm{q} 36.3::)$; notably there was another $\mathrm{Ph}$-positive clone with trisomy 8 as secondary abnormality [14].

The progression of CML from CP to blast crisis (BC) is frequently associated with nonrandom secondary chromosomal aberrations such as $+8, \mathrm{i}(17 \mathrm{q}),+19$ and an extra $\mathrm{Ph}$ chromosome [16].

Ring chromosomes are rare cytogenetic abnormalities that occur in less than $10 \%$ of hematopoietic malignancies but have been reported in up to $70 \%$ of mesenchymal tumors [3].

Monosomy 7 or deletion of $7 \mathrm{q}$ in these disorders is associated with poor prognosis [17]. It has been hypothesized that there is a tumor suppressor gene (TSG) on chromosome arm 7q that contributes to the pathogenesis of these diseases [18]. However, monosomy 7 or structural abnormalities resulting in the deletion of $7 \mathrm{p}$ were infrequent in childhood ALL to confer increased risk of treatment failure in $\mathrm{Ph}$-positive cases, and it has been hypothesized that a TSG on $7 \mathrm{p}$ may contribute to the poor outcome of these patients [6].

Both monosomy 7 and del (7p) are of the additional chromosomal abnormalities and they associated with adverse prognostic factors in CML patients treated with IM as a frontline therapy $[19,20]$.

Recent studies have reported that major route abnormalities such as trisomy 8 at diagnosis were related to a worse outcome $t(9,22)[20,21]$.

In conclusion, we reported here a novel case of a $\mathrm{Ph}$ chromosome positive CML in chronic phase with a new cytogenetic abnormality $\mathrm{r}(7)$ resulting in the deletion of $7 \mathrm{p}$ and immunophenotyping was consistent with CML although $4.5 \%$ of total leucocytes showed acute myelogeneous leukemia (AML) subtype M2. The r(7) and del $7 \mathrm{p}$ might be a marker for adverse prognosis in CML.

\section{ACKNOWLEDGEMENTS}

We thank Prof. I. Othman, the Director General of Atomic Energy Commission of SYRIA (AECS) and Dr. N. Mirali, Head of Molecular Biology and Biotechnology Department for their support. This work was supported by the AECS, in parts by the DAAD, Stefan-MorschStiftung and the Monika-Kutzner-Stiftung.

\section{REFERENCES}

[1] La Starza, R., Testoni, N., Lafage-Pochitaloff, M., Ruggeri, D., Ottaviani, E., Perla, G., Martelli, M.F., Marynen, P. and Mecucci, C. (2002) Complex variant Philadelphia translocations involving the short arm of chromosome 6 in chronic myeloid leukemia. Haematologica, 87, 143147.

[2] Lugo, T., Pendergast, A., Müller, A. and Witte, O. (1990) Tyrosine kinase activity and transformation potency of bcr-abl oncogene products. Science, 247, 1079-1082. http://dx.doi.org/10.1126/science. 2408149

[3] Gebhart, E. (2008) Ring chromosomes in human neoplasias. Cytogenetics Genome Research, 121, 149-173. http://dx.doi.org/10.1159/000138881

[4] Luna-Fineman, S., Shannon, K.M. and Lange, B.J. (1995) Childhood monosomy 7: Epidemiology, biology, and mechanistic implications. Blood, 85, 1985-1999.

[5] Le Beau, M.M., Albain, K.S., Larson, R.A., Vardiman, J.W., Davis, E.M., Blough, R.R., Golomb, H.M. and Rowley, J.D. (1986) Clinical and cytogenetic correlations in 63 patients with therapy-related myelodysplastic syndromes and acute nonlymphocytic leukemia: further evidence for characteristic abnormalities of chromosomes no. 5 and 7. Journal of Clinical Oncology, 4, 325-345.

[6] Heerema, N.A., Nachman, J.B., Sather, H.N., La, M.K., Hutchinson, R., Lange, B.J., Bostrom, B., Steinherz, P.G., Gaynon, P.S., Uckun, F.M. and Children's Cancer Group. (2004) Deletion of $7 p$ or monosomy 7 in pediatric acute lymphoblastic leukemia is an adverse prognostic factor: A report from the Children's Cancer Group. Leukemia, 18, 939-947. http://dx.doi.org/10.1038/sj.leu.2403327

[7] Claussen, U., Michel, S., Mühlig, P., Westermann, M., Grummt, U.W., Kromeyer-Hauschild, K. and Liehr, T. (2002) Demystifying chromosome preparation and the implications for the concept of chromosome condensation during mitosis. Cytogenetics Genome Research, 98, 136146. http://dx.doi.org/10.1159/000069817

[8] Shaffer, L., Slovak, M. and Cambell, L. (2009) ISCN (2009): An international system for human cytogenetic nomenclature. S. Karger, Basel.

[9] Al-Achkar, W., Wafa, A. and Nweder, M.S. (2007) A complex translocation $t(5 ; 9 ; 22)$ in Philadelphia cells involving the short arm of chromosome 5 in a case of chronic myelogenous leukemia. Journal of Experimental and Clinical Cancer Research, 26, 411-415.

[10] Liehr, T., Heller, A., Starke, H., Rubtsov, N., Trifonov, V., Mrasek, K., Weise, A., Kuechler, A. and Claussen, U. 
(2002) Microdissection based high resolution multicolor banding for all 24 human chromosomes. International Journal of Molecular Medicine, 9, 335-339.

[11] Al-Achkar, W., Wafa, A., Ali, B.Y., Manvelyan, M. and Liehr, T. (2010) A rare chronic myeloid leukemia case with Philadelphia chromosome, BCR-ABL e13a3 transcript and complex translocation involving four different chromosomes. Oncology Letters, 1, 797-800.

[12] Al-Achkar, W., Wafa, A., Klein, E. and Aljapawe, A. (2011) Biclonal myelodysplastic syndrome involving six chromosomes and monoallelic loss of RB1-A rare case. Molecular Cytogenetics, 4, 16. http://www.molecularcytogenetics.org/content/4/1/16 http://dx.doi.org/10.1186/1755-8166-4-16

[13] Tamaska, J., Adam, E., Kozma, A., Gopcsa, L., Andrikovics, H., Tordai, A., Halm, G., Bereczki, L., Bagdi, E. and Krenacs, L. (2006) Hepatosplenic gammadelta T-cell lymphoma with ring chromosome 7 , an isochromosome 7q equivalent clonal chromosomal aberration. Virchows Archives, 449, 479-483. http://dx.doi.org/10.1007/s00428-006-0267-5

[14] Raimondi, S.C., Chang, M.N., Ravindranath, Y., Behm, F.G., Gresik, M.V., Steuber, C.P., Weinstein, H.J. and Carroll, A.J. (1999) Chromosomal abnormalities in 478 children with acute myeloid leukemia clinical characteristics and treatment outcome in a cooperative pediatric oncology group study POG 8821. Blood, 94, 3707-3716.

[15] Fujino, H., Fujita, N., Hamamoto, K., Oobu, S., Kita, M., Tanaka, A., Matsubara, H., Watanabe, K., Heike, T. and Adachi, S. (2010) Ring/marker chromosome derived from chromosome 7 in childhood acute megakaryoblastic leukemia with monosomy 7. International Journal of Hematology, 92, 386-390. http://dx.doi.org/10.1007/s12185-010-0663-0

[16] Mitelman, F., Johansson, B. and Mertens, F. (2013) Mitelman database of chromosome aberrations in cance. http://cgap.nci.nih.gov/Chromosomes/Mitelman

[17] Mrozek, K., Heinonen, K. and Bloomfield, C.D. (2000) Prognostic value of cytogenetic findings in adults with acute myeloid leukemia. International Journal of Hema- tology, 72, 261-271.

[18] Le Beau, M., Espinosa III, R., Davis, E.M., Eisenbart, J.D., Larson, R.A. and Green, E.D. (1996) Cytogenetic and molecular delineation of a region of chromosome 7 commonly deleted in malignant myeloid diseases. Blood, 88, 1930-1935.

[19] Lee, S.E., Choi, S.Y., Bang, J.H., Kim, S.H., Jang, E.J., Byeun, J.Y., Park, J.E., Jeon, H.R., Oh, Y.J., Kim, M. and Kim, D.W. (2012) The long-term clinical implications of clonal chromosomal abnormalities in newly diagnosed chronic phase chronic myeloid leukemia patients treated with imatinib mesylate. Cancer Genetics, 205, 563-571. http://dx.doi.org/10.1016/j.cancergen.2012.09.003

[20] Luatti, S., Castagnetti, F., Marzocchi, G., Baldazzi, C., Gugliotta, G., Iacobucci, I., Specchia, G., Zanatta, L., Rege-Cambrin, G., Mancini, M., Abruzzese, E., Zaccaria, A., Grimoldi, M.G., Gozzetti, A., Ameli, G., Capucci, M.A., Palka, G., Bernasconi, P., Palandri, F., Pane, F., Saglio, G., Martinelli, G., Rosti, G., Baccarani, M., Testoni, N., and Gruppo Italiano Malattie Ematologiche dell'Adulto (GIMEMA) Working Party on CML. (2012) Additional chromosomal abnormalities in Philadelphiapositive clone: Adverse prognostic influence on frontline imatinib therapy: A GIMEMA Working Party on CML analysis. Blood, 120, 761-767. http://dx.doi.org/10.1182/blood-2011-10-384651

[21] Fabarius, A., Leitner, A., Hochhaus, A., Müller, M.C., Hanfstein, B., Haferlach, C., Göhring, G., Schlegelberger, B., Jotterand, M., Reiter, A., Jung-Munkwitz, S., Proetel, U., Schwaab, J., Hofmann, W.K., Schubert, J., Einsele, H., Ho, A.D., Falge, C., Kanz, L., Neubauer, A., Kneba, M., Stegelmann, F., Pfreundschuh, M., Waller, C.F., Spiekermann, K., Baerlocher, G.M., Lauseker, M., Pfirrmann, M., Hasford, J., Saussele, S., Hehlmann, R. and Schweizerische Arbeitsgemeinschaft für Klinische Krebsforschung (SAKK) and the German CML Study Group. (2011) Impact of additional cytogenetic aberrations at diagnosis on prognosis of CML: Longterm observation of 1151 patients from the randomized CML Study IV. Blood, 118, 6760-6768. http://dx.doi.org/10.1182/blood-2011-08-373902 